about four times as rich as the northerm in bright, early $B$ stars, the determination of accurate gradients and spectral types for these stars should assist materially in the elucidation of the present uncertain colour spectrum relation from $O$ to $B 3$. This is a matter of fundamental importance in studying inter. stellar reddening and galactic structure in general.

Approval has been received for the acquisition of a 74-inch reflector as recommended by the Astronomer Royal when he visited the Observatory in February 1947 , and, while negotiations have been opened with Sir Howard Grubb, Parsons and Co., Ltd., for the construction of an instrument similar to the Radcliffe telescope, a final contract has not yet been arranged. All the smaller mirrors attached to the Observatory have been aluminized by means of the N.R.C. evaporating plant obtained from the Munitions Department, which has also supplied a 42-inch aluminizing tank; this should enable all the existing glass mirrors in the Observatory to be aluminized.

The Ionospheric Prediction Service, which had previously been operated by the Radio Research Board, has been transferred by that body to the Department of the Interior, and attached to the Commonwealth Observatory. It issues two monthly publications-"Radio Propagation Bulletin" and "Tables of Frequency Bands to be used by Ships and Aircraft for Communication with Australian Bases"and also an annual report on long-term forecasting.

\section{MITES AND STORED FOOD PRODUCTS}

$T_{h}^{H}$ HE mites associated with stored food products have received much less attention from biologists than the insect pests found with them. For one thing, students of Acari are few, and mites are often hard to identify. Also, much of the leading systematic writings on these creatures has been published in various languages and in journals that are often very inaccessible. Under the title of "The Mites Associated with Stored Food Products"*, Mrs. A. M. Hughes has written a useful paper that has recently been ssued on behalf of the Ministry of Agriculture and Fisheries. The Department of Scientific and Industrial Research inaugurated a study of the biology of mites, while the Ministry of Food stationed an officer, Mrs. M. Kendall, at the British Museum (Natural History) to study their systematics. She was followed in this work by Mrs. A. M. Hughes, of the Royal Free Hospital School of Medicine, who was deputed to work on a part-time basis, attached to the Infestation Division of the Ministry of Food. This latter Division, it may be added, was transferred to the Ministry of Agriculture and Fisheries in September 1947.

If food be kept in store for any length of time, mites are very liable to infest it and increase to incredible numbers, contaminating it with their excreta and dead bodies. The present publication deals with the mites that affect stored food products, together with the kinds that prey upon them. Also included are certain mites that feed upon small fungi or are parasites on insects or rats. While the biology of many of the mites that are enumerated is unknown, the present descriptive account will serve as a guide

* The Mites Associated with Stored Food Products. By A. M.
Hughes. Pp. 168. (London: H.M. Stationery Office, 1948.) to their identification and, thereby, provide the basis for more extended investigations. The segmentation of the body in mites is peculiarly developed, which makes it difficult to homologize the regions thus demarcated with corresponding areas in other Arthropoda. For this reason, new names are given to the different regions of the body that are displayed in these creatures.

Three sub-orders of mites are recognized, namely, the Sarcoptiformes, Trombidiformes and Parasitiformes. Of the first-named group the Tyroglyphoidea cause the most severe damage. They are small whitish mites occurring in all kinds of stored products when the relative humidity of the immediate environment is 70 per cent or more. Among their members one of the commonest is Glycyphagus domesticus, which not only affects dried food materials but often occurs in enormous numbers in furniture stuffed with untreated Algerian fibre, where it feeds on fungi growing on the fibre. Among the Trombidiformes are many brightly coloured mites, including the familiar 'red spiders'. Some of them are represented in the stored product fauna, where they are predaceous upon other mites or on small insects. The Parasitiformes are highly specialized mites that are divided into the two groups, Ixodides, which do not affect stored products, and the Mesostigmata, which prey upon other mites, insects or small mammals, such as rats and mice.

When collecting mites the use of Oudemans' mix. ture is advised in preference to spirit or formalin. For temporary mounts a 60 per cent solution of lactic acid is satisfactory, while for more permanent preparations a mixture of polyvinol alcohol and lactophenol is better than gum chloral for small species. The composition of these several media is given at the end of the bulletin. There is also a short list of the essential literature dealing with the various groups of mites. The accounts given of the different species are very concise and their value is enhanced by the very numerous figures of structural details.

A. D. Iмms

\section{FORTHCOMING EVENTS}

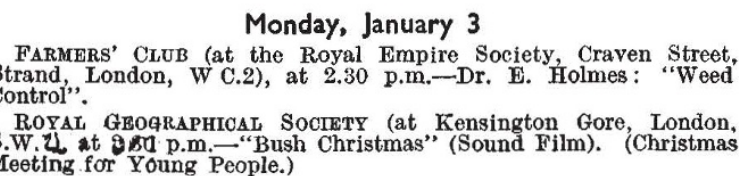

Tuesday, January 4 ROYAL SOCIETy of ARTS (at John Adam Street, Adelphi, London,
W.C.2), at 6 p.m.-Lieut. P. G. Satow : "Radar and its Application to the Science and Art of Marine Navigation".

Wednesday, January 5

SOCIETY OF CHEMICAL INDUSTRY, NUTRITION PANEL OF THE FOOD GRovP (at Gas Industry House, 1 Grosvenor Place, London, S.W.1), at 6.30 p.m.-Discussion on "The Sausage as Food".

INSTITUTE OF WELDING, MANCHESTER AND DISTRIOT BRANCH (in the Reynolds Hall, College of Technology, Manchester), at 7 p.m.Mr. R. R. Sillifant: "Recent Developments in Oxygen Cutting".

\section{Friday, January 7}

Textile Institute, Lancashire Section (at the Textile Institute, 16 St. Mary's Parsonage, Manchester), at 1 p.m.-Mr. L. W. Coxon: "The Philosophy of Management".

SOCIETY of CHEMICAL INDUSTRY, MANCHESTER SECTION (joint meeting with the LOCAL SECTIONS of the CHEMICAI SOCIETY and the ROYAL INSTITUTE OF CHEMrSTRY, at the Engineers' Club, Albert Square, Manchester), at 6.45 p.m.--Dr. H. Steiner: "Production of Acetylene from Hydrocarbons;"

PAPER Makers' Association, TeChNiCAL SECTION, NORTHERN DIVISION (at the Engineers' Club, Albert Square, Manchester), at 7 p.m. $\rightarrow$ Mr. H. R. Hutley : "The Technical Education of Juveniles in the Paper Industry-Practical Considerations". 